\author{
E. J. Clery
}

\title{
HORACE WALPOLE, THE STRAWBERRY HILL PRESS, AND THE EMERGENCE OF THE GOTHIC GENRE
}

Keywords: Horace Walpole, Strawberry Hill Press, gothic novel, manuscript vs. print culture

The Castle of Otranto, often described as the first Gothic novel, appeared in December 1764 heavily disguised. On the title page of the first edition, it was announced as a translation by "William Marshall, Gent. From the Original Italian of Onuphrio Muralto, Canon of the Church of St. Nicholas at Otranto." The true author, Horace Walpole, did not put his name to it. Instead, he created an elaborate fake publishing history for the work, outlined in the preface:

The following work was found in the library of an ancient catholic family in the north of England. It was printed at Naples, in the black letter, in the year 1529. How much sooner it was written does not appear. The principal incidents are such as were believed in the darkest ages of christianity; but the language and conduct have nothing that savours of barbarism. The style is the purest Italian. If the story was written near the time when it is supposed to have happened, it must have been between 1095, the aera of the first crusade, and 1243, the date of the last, or not long afterwards. (Walpole, 1996, 5)

The reason Walpole presented Otranto as a counterfeit work of the Italian middle ages becomes apparent once one looks at the reviews of the first edition. The anonymous critic in the Monthly Review has entirely swallo- 
wed the bait; he reproduces the information from the preface just noted and gives his judgment, "a work of genius, evincing great dramatic powers, and exhibiting fine views of nature, the Castle of Otranto may still be read with pleasure" (February 1765, 97-99, my emphasis). ${ }^{1}$ The critic in the rival review journal of the day, the Critical Review, is more wary, and his judgment more damning. He too begins by citing the fake publishing history: "Such is the character of this work given us by its judicious translator; but whether he speaks seriously or ironically, we neither know nor care. The publication of any work, at this time, in England composed of such rotten materials, is a phenomenon, we cannot account for" and he goes on to itemize "the absurdity of its contents" (January 1765, 50-51). ${ }^{2}$

Today, we see Gothic fiction as a fixture in the literary marketplace. Harry Potter and Twilight are only two of the highly successful global franchises in recent years; Gothic's appeal and its selling power seem inexhaustible. Thus it is particularly interesting to note the resistance to a revival of improbable works of the imagination revealed by the original reception of Otranto and Walpole's initial ploy. After the first print-run of five hundred copies quickly ran out, Walpole then prepared a second edition, with a new title page and a new preface acknowledging his authorship with the initials "H. W." This appeared four months after the first.

This time, on the title page, The Castle of Otranto was subtitled "A Gothic Story" instead of simply "A Story." Walpole is defiant: at the very moment he reveals that the work is by a modern author, he calls it "Gothic." At this time the term had two principal meanings: first, "Gothic" was used of anything belonging to the period stretching from the fall of the Roman Empire to the revival of classical learning in the Renaissance and, in Britain, the Reformation; second, it was a derogatory term, meaning strange, outmoded, or grotesque. By the mid-eighteenth century, with the development of a consumer society and the restless search for novelty, the Gothic was so far out of fashion that among the elite it had become fashionable in the form of garden ornaments, interior decoration, and a taste for antiquities, ar-

1 The review has been anthologized in a number of publications including Sabor (1987), Clery and Miles (2000), and Gamer (2001).

2 Anthologized in publications referred to in the previous note. 
chitectural and literary. Yet Walpole's creation of fantasy fiction based on superstitious belief, and his willingness to disseminate it to a wide and undiscriminating audience, still had the power to shock.

Walpole justifies the experiment in a number of ways. There is a Latin epigraph on the title page of the second edition: “--- Vanae / Fingentur species, tamen ut Pes, \& Caput uni / Reddantur formae. --- Hor.” This is a play on lines from Horace's Ars Poetica, one of the foundations of neoclassical aesthetic theory. The correct translation of the original lines is: "idle fancies shall be shaped [like a sick man's dream] so that neither foot nor head can be assigned to a single shape". Walpole has reversed the meaning by saying "nevertheless head and foot are assigned a single shape". There are two levels of meaning here. In the first instance, there is a joking reference to the plot: the ghostly dismembered limbs of the former ruler of Otranto, Alfonso the Good, are eventually put back together, fulfilling a prophecy that literally destroys the house of the tyrant and usurper, Prince Manfred. At a meta-narrative level, Walpole's alteration seems to counter neoclassical aesthetics. Horace had suggested that improbabilities-monstrous fancies-are a kind of sickness. Walpole may be asserting that the imagination can nevertheless shape monstrous fancies into a unity: "head and foot are assigned a single shape."

The revised title page was followed by a new preface in which Walpole comes out fighting against his detractors, sweeping aside neoclassical objections to fantasy in fiction, and building up a defense of rule-breaking in Shakespeare, with many patriotic sideswipes at Voltaire as apologist for the more formally restrained French dramatic tradition. I do not intend to dwell here on the aesthetic context for Walpole's experiment. This has been effectively dealt with in many critical works. Similarly, there have been a number of pieces written on the connection between the castle that provides the scenery and atmosphere for The Castle of Otranto and Strawberry Hill. ${ }^{3}$ Instead I want to pause on the print culture context of Otranto.

Among the many fascinating aspects of the Strawberry Hill ménage was the private printing press set up seven years before the publication of

3 Strawberry Hill in Twickenham near London, a villa re-modelled as a neo-Ghotic 'castle', was Walpole's private residence. 
Otranto. The novel was not in fact printed there, no doubt mainly in the first instance to preserve Walpole's anonymity, but it nevertheless emerged from his experiences as a publisher and printer in his own right.

Let us return for a moment to the fake publishing history offered at start of the preface to the first edition. The account is exact. The story itself, on internal evidence, could have been written at some point during the Crusades but after the establishment of Spanish rule in Naples, probably in the thirteenth century, and survived in manuscript. However the "translator" William Marshal speculates that it is of more recent date, not long before the time when was "printed at Naples, in the black letter, in the year 1529." This is the time of the Counter-Reformation, and Walpole sketches out a little narrative-an Enlightenment narrative-about the way the enlightening role of the printing press was subverted.

Letters were then in their most flourishing state in Italy, and contributed to dispel the empire of superstition, at that time so forcibly attacked by the reformers. It is not unlikely that an artful priest might endeavour to turn their own arms on the innovators, and might avail himself of his abilities as an author to confirm the populace in their ancient errors and superstitions. If this was his view, he has certainly acted with signal address. Such a work as the following would enslave a hundred vulgar minds beyond half the books of controversy that have been written from the days of Luther to the present hour. (Walpole, 1996, 5)

This passage becomes particularly striking when the true authorship of the story becomes known. "Onuphrio Muralto," cited on the first title page, is revealed to be Horace Walpole himself; he is the "artful priest," renewing and circulating superstition-the identification is reinforced through a playful mistranslation, "Muralto" vaguely approximating to "Walpole." The laissez-faire attitude toward fiction as mere entertainment and escapism had not yet taken root, and the hoodwinked critic of the Monthly Review was gratifyingly outraged.

While we considered [this book ... as a translation from an old Italian romance] we could readily excuse its preposterous phenomena, and consider them as sacrifices to a gross and unenlightened age. -But when, as in this edition, the Castle of Otranto is declared to be a modern performance, that indulgence we 
afforded to the foibles of a supposed antiquity, we can by no means extend to the singularity of a false taste in a cultivated period of learning. It is, indeed, more than strange, that an Author, of a refined and polished genius, should be an advocate for re-establishing the barbarous superstitions of Gothic devilism! (May 1765, 394)

The reviewer finds it strange that a refined and polished author "should be an advocate for re-establishing" Gothic superstition. Previously, in The Rise of Supernatural Fiction (1995), I took this paradox in the direction of investigating eighteenth-century ideas of change and progress. Here I want to take it in a different direction. My question, arising from reviewer's outburst, is this: What kind of author was Walpole? What indeed might lead "an Author, of a refined and polished genius" to "be an advocate for re-establishing ... Gothic devilism"? To answer this, I think it is necessary to reassess Walpole's orientation toward print.

Strawberry Hill Press was set up in June 1757, "the first private press of importance in England," in a small building close to the house (Sabor, 1987, 4). Walpole was to employ a succession of printers to work it, and they were kept busy. Thirty-four books were published there over the thirty-two years from 1757 to 1789, and Walpole himself authored or edited fourteen of them. R. W. Ketton-Cremer, in his biography of Walpole, remarks on the printing press at Strawberry Hill,

since it was difficult to own a private press without succumbing to the temptations of authorship, W's literary ambitions were immediately stimulated. The bulk of his most important and most original literary work belongs to the ten or twelve years which followed its establishment. (Ketton-Cremer, 1940, 187)

This is a persuasive picture. After all, the best-known works by Walpole all appear after that date. There is something rather seductive about the notion that it was the very existence of a printing press, readily to hand, that generated Walpole's identity as an author. Technology comes first; authorship second. See Appendix One for the list of books that Ketton-Cremor probably had in mind, almost all of them printed at Strawberry Hill, with a couple of significant exceptions: The Castle of Otranto itself, as noted, and 
Historic Doubts on the Life and Reign of King Richard the Third, published by Dodsley in 1768 .

However plausible this view of career is, I propose that it needs to be put aside in order to regain some of the actual complexity of Walpole's relationship with print culture and to properly locate his sense of what it was to be an author. Appendix two is a list of Walpole's publications before the establishment of the Strawberry Hill Press. It is surprisingly long and varied, including anonymous ephemera, mainly political pamphlets, and a weighty monument of filial devotion, the Aedes Walpolianae, a glorification of the art collection of his father, the former Prime Minister Robert Walpole. The most obvious classification might be according to genre: politics and belles lettres. However, this division is difficult to sustain. Even the 1746 poem The Beauties: An Epistle to Mr Eckhardt the Painter is in fact a compliment to the wife of one of the leading Whig politicians.

An alternative pattern appears according to the mode of publication; that is to say, whether the work was pirated, a gift-book, or a deliberate commercial enterprise on Walpole's part. These diverse routes into print are all, I argue, relevant to Walpole's eventual publication of a "Gothic Story." Below I consider the implications of each in more detail.

\section{Piracy}

With two of his very earliest printed works, The Lessons for the Day (1742) and The Beauties (1746), Walpole apparently fell victim to unscrupulous printers.

In some manuscript notes Walpole describes how The Lessons for the Day, a short satirical piece on corruption among his father's political enemies, was originally written into a private letter to his friend Horace Mann. While Walpole was in the act of writing it, an acquaintance, Edward Coke, son of Lord Lovel, entered the room, made a copy, "and dispersed it till it got into print, but with many additions, and was the origin of a great number of things of that sort" (Hazen, 1948, 19). The accident, in other words, become productive of a series of similar political pamphlets-and despite 
its faulty and unauthorized appearance, its success gave encouragement to Walpole's authorial ambitions.

Similarly with The Beauties, as Walpole recorded: "In July . . . [1746] I wrote The Beauties, which was handed about till it got into print, very incorrectly" (Hazen, 1948, 22). There was an intricate history behind this brief statement. Although this poem was addressed to the portraitist Eckhardt, it was originally sent in a letter to Henry Fox as compliment to his wife Caroline. It was part of a system of political favor and patronage that involved the transmission of texts outside the economy of print. Fox was pleased with it, and announced his intention to have it published, but Walpole begged him not to. Nevertheless, the verses were passed around in manuscript form until they found their way into print, with "several errors." Walpole wrote to Horace Mann on 12 November 1746 to explain why he had not sent the published lines: "I never wrote anything that I esteemed less ... I was hurt at their getting into print" (Hazen, 1948, 22-23). Once the deed was done, however, for the sake of authorial honor he seems to have approved a partially corrected reprinting in Dodsley's Collection of Poems, 1748, and then, perhaps gratified by the reception, he reprinted the poem himself in Fugitive Pieces, 1758. It also appeared in his collected Works, 1770 and 1798.

Piracy, the printing of texts without the author's permission or supervision, has long been a feature of print culture. There are monographs on the subject dealing with the Elizabethan period and seventeenth century. However, as can be seen in the case of Walpole and his friends, this unwilling, potentially compromising method of being dragged into print was still rife in the mid-eighteenth century. In her 1999 study Social Authorship and the Advent of Print, Margaret Ezell looks at the persistence of this phenomenon and sheds brilliant light on its implications. She challenges assumptions of the primacy of print and the regressive nature of manuscript exchange, and takes seriously the reasons authors themselves give for wishing to restrict their public to a small coterie and avoid the commercial process. One of the reasons is the possibility of an inaccurate or corrupt copy being enshrined in print. This obviously exercised Walpole. As Ezell remarks, "one is struck by the connection between print and bad copies, between print and the distortion of the literary, social author" (Ezell, 1999, 48). 
When one looks at Walpole's career as a writer, the figure of Thomas Gray, a close friend and leading pre-Romantic poet, emerges as a kind of authorial alter ego. A great deal of what is ambivalent in Walpole's relation to commercial print culture is prefigured in Gray's tortured attitude to publication. Thomas Gray had been a friend of Walpole's since their schooldays at Eton. On 12 June 1750 he sent Walpole a handwritten copy in a letter of a poem he had just written, "Elegy Written in a Country Churchyard"-eventually to become one of the most celebrated poems in English. Everyone knows the lines:

Full many a flower is born to blush unseen

And waste its sweetness on the desert air

This is a poem about mortality, and also about the fate of being buried in the country, whether alive or dead, with one's talents unacknowledged publicly. Gray himself was compulsively retiring and his friendship with Walpole an ongoing tragicomedy of Gray retreating from publication and Walpole pushing him towards it, whether intentionally or inadvertently. Ketton-Cremer recounts of the Elegy:

Somewhat to Gray's annoyance, Walpole showed the astonishing production to all his friends. Copies were taken, and early in the following year one of them reached the proprietors of a dingy periodical called The Magazine of Magazines, who informed Gray that they proposed to print it in their next issue. Gray then asked Walpole, as the person responsible for his embarrassment, to make amends by arranging with Dodsley for the immediate publication of the poem. Walpole duly saw the poem through the press, and added at Gray's request an unsigned note explaining how it had come into the printer's hands. Its success was immediate and overwhelming. (Ketton-Cremor, 1940, 163)

Once again, as with Walpole's The Beauties, Robert Dodsley came to the rescue, publishing a corrected version at the request of the author when a work had been abducted by pirates. This well-known and highly respected publisher is a fascinating figure within print culture. Dodsley had begun his working life as a manservant, and had published two books of his own poems under the titles Servitude: A Poem of a Footman (1729) and A Muse in 
Livery; or the Footman's Miscellany (1732). He set up a bookselling business in 1735 with financial aid from Alexander Pope. It is easy to imagine that he was peculiarly well-equipped to deal with the sensibilities of gentleman authors more at home with the private circulation of manuscript poems.

After the triumph of Gray's Elegy, Walpole went on to propose publishing with Dodsley a collection of Gray's poems illustrated by another friend, Richard Bentley. Gray agreed only on the basis that it was a device to gain publicity for the illustrator, "stipulating that the book was to be entitled Designs by Mr. R. Bentley, for Six Poems by Mr. T. Gray" (KettonCramer, 1940, 165).

However, Walpole conspired in the preparation of an engraving taken from the Eckhardt portrait of Gray that he owned to serve as frontispiece for the volume. Gray was predictably horrified. He recoiled from anything that might suggest authorial vanity or seeking after publicity. At the same time-and I think this has echoes in Walpole's publication of Castle of Otranto-Gray seems to have seen commercial publication as the ultimate test of the value of his writing. Within a predominantly scribal literary culture, where authorial identity is essentially private, the presentation of compositions before the public is momentous. One should not underestimate the significance of going into print for an author. Looking at the experience of Gray somewhat explains Walpole's own attitude: a mixture of hesitancy in acknowledging authorship and a combative approach to cultural norms.

Walpole, I wish to suggest, was, like Gray, first and foremost a scribal author. His identity as a writer was founded on manuscript production to be circulated among a limited audience in the first instance, and aimed at posterity beyond that, and not immediate public recognition. The evidence for this lies mainly in the extraordinary achievement of his correspondence; a form of writing I have not mentioned up to this point because it remained unpublished at his death. Walpole had no need to write for money (more on this below), yet he must have been one of the century's most prolific writers in English. He was hugely productive as a letter writer; the Yale edition of his correspondence consists of forty-eight large printed volumes. He regarded this body of writing as his major life's work. From an early age, he kept copies of his letters or else demanded the return of the original she- 
ets from recipients. He saw the correspondence as a chronicle of the times, to be carefully preserved in manuscript form. When considering Walpole's publishing activities during his lifetime, this vast submerged body of work needs to be kept in mind.

\section{Gift Books}

Two of Walpole's early publications might be included in the category of "gifts", and this print form was to be a feature throughout his career. The first was a Latin poem written at the age of 19 , included in a University of Cambridge of 1736 "collection honouring the marriage of the Prince of Wales" (Sabor, 1987, 3). The second was the previously mentioned Aedes Walpolianae: or, A Description of the Collection of Pictures at HoughtonHall. This was privately printed in an edition of one-hundred copies, of which eighty-three were distributed as gifts. From an early stage in his career, then, publishing was associated for Walpole with magnificence, and with his function as a member of the aristocratic elite. His establishment of the first private printing press in England may have come about with patronage in mind. As Ketton-Cremer remarks, he was no doubt conscious of Gothic precedents: aristocrats served as patrons to Caxton, who established the very first printing press in England in $1476(1948,187)$.

Among the roles of a patron listed by Dustin Griffin in Literary Patronage in England 1650-1800 is "magnificence," a political virtue. It was the duty of a cultivated patrician to display his wealth and expend it on writers and artists. This might include the distribution of books as gifts to friends. There was a great Whig tradition of literary patronage: Somers, Dorset, and Halifax - all in high political office-dispensed patronage to writers such as Addison, Steele and Swift, wrote poetry themselves, and built up large book collections, as did Walpole (Griffin, 1996, 46-51). His own father Robert Walpole, although he was berated by the Tory wits for his lack of taste and munificence was, Griffin judges, "unsurpassed in his use of patronage to consolidate his political power" (ibid., 55). 
In the spirit of this tradition Walpole wrote his Catalogue of Royal and Noble Authors (1758), a politically partisan survey of the class of writers Pope dubbed "holiday writers ... gentleman that diverted themselves now and then with poetry, rather than as poets" (in Ezell, 1999, 62). But it is possible to see in his career a gradual transition to a more commercial outlook, including an awareness of the public benefits of a wider dissemination of print, beyond the gift economy or the restricted market in fine editions. In 1752 he arranged for publication of a larger commercial edition of Aedes Walpolianae printed for Dodsley, with another in 1767. In 1782 (24 May) he wrote to his friend Cole explaining the rationale of an economy five-volume edition of his Anecdotes of Painting in England and Catalogue of Engravers: "It is a cheap edition for the use of artists ... at least they who really want the book ... may have it, without being forced to give the outrageous price at which the Strawberry Hill edition sells, merely because it is rare" (Walpole, Correspondence, vol. 2, 319).

In line with this enterprise, it is possible to detect an increasing impatience in his correspondence with gift-giving. In 1773 (18 February) he grumbled to Cole about the poor sales of Miscellaneous Antiquities, a Strawberry Hill publication. Five hundred had been printed, but only 130 sold:

I cannot afford to make the town perpetual presents, though I find people exceedingly eager to obtain them when I do: and if they will not buy them, it is a sign of such indifference, that I shall neither bestow my time or my cost to no purpose. (Correspondence, vol. 1, 300)

\section{Commercial Publishing}

In writing the first Gothic novel, Walpole as author also represents a new type in the history of fiction writing. He was not desperate for money, like the vast majority. Nor was he a print culture insider with an itch for scribbling and a moral mission like Samuel Richardson; the most influential author of fiction in English to date. Horace Walpole lived a life of privilege and financial security, funded by sinecures-government offices that generated income but involved no work (he was usher of the exchequer, 
comptroller of the pipe, and clerk of the estreates). ${ }^{4}$ As the scion of the best known Whig family in the country, he naturally became a member of the parliament and was involved in politics. However, he was mainly absorbed in the private passions of antiquarianism, collecting old books and pictures, and small-scale artistic patronage. Walpole was a writer that did not need to write, and the effect was liberating.

The literary marketplace intrigued him, and he could afford to take a detached view of it. He was exhilarated by the rapid sale of the 2,000 copies of Gray's Six Poems, and fascinated by the "take off" of his own satirical pamphlet A Letter from Xo Ho, A Chinese Philosopher at London (1757), which sold for sixpence. He recorded: "May 12 of that year, I wrote in less than an hour and a half the Letter from Xo Ho, it was published on the $17^{\text {th }}$, and immediately passed through five editions" (in Hazen, 1948, 39). In the same year he was chastened by the initial critical failure of Gray's poem The Bard, the first publication of the Strawberry Hill Press.

The outsider perspective informs the publishing history and paratext of The Castle of Otranto. The sidelong entry into the marketplace under cover of anonymity has already been discussed. As his publisher Walpole chose not the up-market Dodsley, but Thomas Lowndes, a mainstream fiction specialist and an innovator in the development of circulating libraries as a linked outlet for the bookselling business. The original edition consisted of five hundred copies, with another five hundred printed for the second edition.

The critic of the Monthly Review sees in the superior production values of this second edition evidence of the authorship: "From the initials, H. W., in this edition, and the beauty of the impression, there is no room to doubt that it is the production of Strawberry Hill" $(1765,394)$. These material signs of elite "gift" publishing make all the more puzzling Walpole's defense in the second preface of "all the trash of Shakespeare." The elements, such as comic grotesquery and superstition, which "that great genius evidently threw out as a necessary sacrifice to that idol the caecum vulgus [blind multitude] he would adopt in the worship of the true God of Poetry." The

4 See Oxford Dictionary of the National Biography for details of Horace Walpole's income. 
reviewer is indignant. Walpole, as a member of the patrician class, should be an upholder of the hierarchy of taste founded on education and wealth. Instead, however, he caters to the lowest prejudices of the common reader.

Walpole makes it clear in the second preface that he has made sales the test of whether or not to "come out" as author and that he defies the opinions of the critics. He begins by stating that the "favourable manner in which this little piece has been received by the public" has been his motivation for revealing its true origins. Initially it seems that he might mean the critic, as spokesman of the reading public: he speaks of "impartial judgement" and of "better judges" (than himself), determining whether he will come forward as author, suggesting a written or verbalized verdict on the work. Ultimately, however, he makes it clear that he refers rather to the more eloquent language of sales figures. He concludes "Such as it is, the general public have honoured it sufficiently, whatever rank their suffrages allot to it" $(1996,14)$. Here, as I have previously noted, Walpole seems to be playing on the idea of a "republic of letters," suggesting that the general public has already ensured the success of The Castle of Otranto, regardless of how the critics with their "suffrages"-their officially "enfranchised" opinion-rate it. ${ }^{5}$

\section{Conclusion: A Mixed Economy of Writing}

I hope this discussion has offered some sort of picture of the way in which Otranto emerges out of three interlocking literary cultures: the world of the social author and of manuscript exchange, the gift economy of print based on the court and the beau monde, and the commercial publishing industry emerging in London. Walpole and Strawberry Hill Press were situated at the intersection of these three realms. This was not an entirely safe or secure place to be.

Walpole, by becoming an independent printer and publisher, establishes himself as a gatekeeper between one world and the next. His press allows him some measure of control: to express his position as patrician

5 See Clery $(1996,120)$ and Clery $(1995,65-66)$. 
and patron, through creation of elite gift books; to suppress his own writings should he have second thoughts, as in the instance of The Mysterious Mother (until eventually, as was inevitable, it was threatened by piracy); to transform manuscript into print, as he did by buying and publishing the manuscripts of George Vertue for Anecdotes of Painting or Lord Herbert of Cherbury, in the same year that Otranto appeared. However, his press also opened him to the experience of the same sort of imposture as he had practiced with Otranto.

The danger of being a recognized gatekeeper becomes apparent in the case of Thomas Chatterton; a case that was to cast a long shadow over Walpole's reputation. Like Walpole himself, Chatterton was a writer that emerged from a culture of manuscript. As a child, the son of a schoolmaster in Bristol, he played with legal manuscripts and somehow gained some antiquarian knowledge: enough to persuade Walpole, when Chatterton first wrote to him in 1769 , at the age of sixteen, that he might possess some genuine medieval writings that could contribute to the endless work of Anecdotes of Painting. He included "transcriptions" of some fragments, including verses by an invented character called Thomas Rowley, and promised more. Walpole was quickly hooked. As Ketton-Cremer remarks, his "enthusiasm may have been partly due to his hopes of obtaining these as material for his press" (1940, 291). However, after making enquiries about Chatterton and showing the pieces to Gray and Mason, who instantly detected them as forgeries, he withdrew. Chatterton, furious, penned the following lines:

Walpole! I thought not I should ever see

So mean a heart as thine has proved to be;

Thou who in Luxury nurs'd behold'st with Scorn

The Boy, who Friendless, Penniless, Forlorn, Asks thy high Favour, - thou mayst call me CheatSay, didst thou ne'er indulge in such Deceit?

Who wrote Otranto? But I will not chide,

Scorn I will repay with Scorn and Pride with Pride. (Sabor, 1987, 156)

Chatterton came up to London to seek his fortune as a writer unsupported, and ended up dead at the age of seventeen, apparently a suicide; his poems were published posthumously, hailed as works of genius. A painting 
by Henry Singleton from 1794, one of several that sought to capture the pathos of his death in a garret, shows the reclining poet surrounded by the papers that would never, in his lifetime, make the transition from the obscurity of manuscript to print publication and fame. The subsequent accession of Chatterton to mythic status enshrined his version of Walpole as a mean-hearted sybarite who, by withholding access to print from a brilliant writer, had damaged English literature.

There has generally been an assumption among scholars that literary culture from the fifteenth century onwards is synonymous with print culture. Manuscript culture is seen as obsolete from the moment Gutenberg sets up the first printing press, and there is believed to be an irrevocable shift from "scribal [authors], manuscript texts and coterie readers to printed texts and a commercial readership" (Ezell, 1999, 6). Print and modernity go hand in hand. One is told of the unstoppable development of the market, and the falling off of private patronage. Sale of copyright has been strictly linked to the development of the author as identity. The premise is that the author generally needs to make money, to sell copyright, and that publishing will generally be a money-making venture.

Gothic has often been discussed as a commercial genre par excellence. It was slow to take off (the first overt imitator of Walpole did not appear until 1773, and the next in 1778), but when Gothic arrived in the 1790s it dominated novel publishing in Britain for around fifteen years. There were then dozens of opportunistic imitators, as Jane Austen reminds us in Northanger Abbey. It was the perfect modern product for the newly-invented circulating libraries that supplied most readers of the time with light entertainment: suspenseful and disposable.

Yet the originator of this literary commodity was a man of leisure, mired in the values and practices of scribal culture and a patronage system that was supposed to have disappeared. It is intriguing that three of the other foremost experimenters of the early Gothic novelists were similarly free of financial imperatives: William Beckford and Matthew Lewis were also the idle wealthy sons of successful fathers; Ann Radcliffe was a comfortably situated housewife with time to kill. 
What one finds in the instance of The Castle of Otranto is the coexistence and interaction of manuscript culture alongside gift and commercial economies of print. Horace Walpole provides a case history of the way in which playful, amateur literary composition continued to feed innovatively into the commercial literary marketplace in the late eighteenth century.

\section{REFERENCES}

Clery, E. J. Introduction. The Castle of Otranto. By Horace Walpole. Oxford: Oxford University Press, 1996, vii-xxxiii.

Clery, E. J. The Rise of Supernatural Fiction, 1762-1800. Cambridge: Cambridge UP, 1995.

Clery, E. J., and Robert Miles, eds. Gothic Documents, A Sourcebook 17001800. Manchester: Manchester UP, 2000.

Critical Review 19 (January 1765).

Ezell, Margaret J. M. Social Authorship and the Advent of Print. Baltimore: Johns Hopkins UP, 1999.

Gamer, Michael, ed. The Castle of Otranto. By Horace Walpole. London: Penguin, 2001, xiii-xxxv.

Griffin, Dustin H. Literary Patronage in England 1650-1800. Cambridge: Cambridge UP, 1996.

Hazen, Allen Tracy. A Bibliography of Horace Walpole. New Haven: Yale UP, 1948.

Ketton-Cremer, Robert Wyndham. Horace Walpole: A Biography. London: Duckworth, 1940.

Monthly Review 32 (February and May 1765).

Sabor, Peter, ed. Horace Walpole: The Critical Heritage. London: Routledge \& Kegan Paul, 1987.

Walpole, Horace. The Castle of Otranto. Oxford: Oxford UP, 1996.

Walpole, Horace. The Yale Edition of Horace Walpole's Correspondence. Ed.

Wilmarth S. Lewis. New Haven: Yale UP, 1973-83. 


\section{Appendix One: Major Works by Walpole after the Establishment of Strawberry Hill Press}

A Catalogue of Royal and Noble Authors. Strawberry Hill Press, 1758.

Fugitive Pieces. Strawberry Hill Press, 1758.

Catalogue of Pictures and Drawings in the Holbein Chamber. Strawberry Hill Press, 1760.

Anecdotes of Painting in England. Strawberry Hill Press, 1762-80.

A Catalogue of Engravers. Strawberry Hill Press, 1764.

The Castle of Otranto. Printed for Thomas Lowndes in Fleet Street, 1765 [1764].

Historic Doubts on the Life and Reign of King Richard the Third. J. Dodsley, 1768. Attributed on title page.

The Mysterious Mother. Strawberry Hill Press, 1768.

\section{Appendix Two: Works Published before the Establishment of Strawber- ry Hill Press}

1736 Latin poem for Gratulatio Academiae Cantabrigiensis.

1742 The Lessons for the Day. London: Printed for W. Webb near St Paul's.

Price Sixpence.

1746 The Beauties: An Epistle to Mr Eckhardt the Painter. London: Printed for M. Cooper, in Paternoster Row. 1746. Price Sixpence.

1746 Epilogue to Tamerlane, On the Suppression of the Rebellion. London:

Printed for R. Dodley at Tully's-head in Pall-mall; and sold by M. Cooper at the Globe in Pater-noster-Row. Price Sixpence.

1747 [1748] Aedes Walpolianae: or, A Description of the Collection of Pictures at Houghton-Hall. London: Printed in the Year 1747.

1747 A Letter to the Whigs. Occasion'd by The Letter to the Tories. London:

Printed for M. Cooper, at the Glebe in Pater-noster-Row.

1748 The Original Speech of Sir W----m St---pe...Feb 19, 1748. London,

Printed for W. Webb, near St. Paul's. Price Sixpence.

1748 The Speech of Richard White-Liver Esq. London, Printed for W. Webb, near St. Paul's, 1748. Price Six-pence.

1753-6 Contributions to The World, published by Robert Dodsley. 
1757 A Letter from Xo Ho, A Chinese Philosopher at London. London: Printed for N. Middleton, in the Strand. 1757. Price Sixpence. 


\section{HORACE WALPOLE, ZALOŽBA STRAWBERRY HILL IN VZNIK GOTSKEGA ŽANRA}

Ključne besede: Horace Walpole, založba Strawberry Hill, gotski roman, rokopisna $v s$. tiskana kultura

\section{Povzetek}

Walpole je Otrantski grad, ki velja za prvi gotski roman, objavil pod preobleko srednjeveškega teksta. Kritiška recepcija ponuja nekaj razlag te potegavščine, a zvijača obenem postavlja vprašanje Walpolovega specifičnega odnosa do tiskane kulture. Prispevek razvija tezo, da ga je oblikovalo lastništvo prve zasebne tiskarne v Veliki Britaniji, založbe Strawberry Hill, pri čemer pa je imel Walpole sebe še vedno za predvsem rokopisnega avtorja. $\mathrm{V}$ članku obravnavam njegove zgodnejše objave in preučujem zapleten sistem objavljanja, posebno pozornost pa namenjam Walpolovemu eksperimentiranju s piratstvom, darilnim založništvom in tržno ekonomijo tiska. 


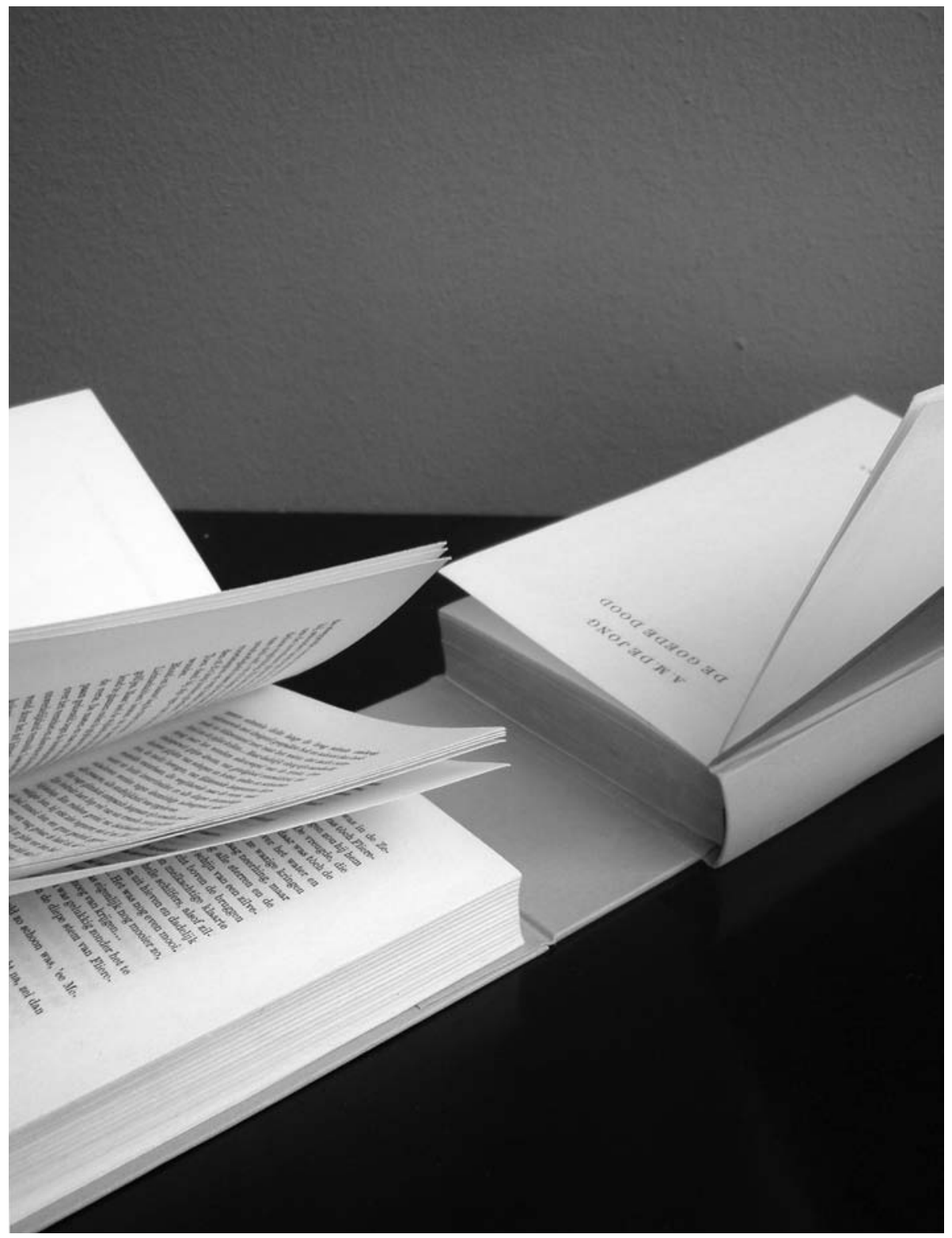

Fleur Thio: A simultaneous book (2009)

"Next to the hasty, the eclectic and the slow book, there is the 'simultaneous book': two books connected to one another. Folded out it provides the opportunity for two people to read from the same book-object at the same time. Sitting opposite of each other they can read a bit and discuss the printed matter simultaneously, thus changing the solitary act of reading into reading alone together." 